\title{
Schistosoma haematobium detection in snails by Dral PCR and Sh110/Sm-SI PCR: further evidence of the interruption of schistosomiasis transmission in Morocco
}

\author{
Fatima Amarir ${ }^{1,3^{*}}$, Faiza Sebti ${ }^{1}$, Ibrahim Abbasi ${ }^{2}$, Abderrahim Sadak ${ }^{3}$, Hajiba Fellah ${ }^{1}$, Haddou Nhammi ${ }^{4}$,
} Btissam Ameur ${ }^{4}$, Abderrahman Laamrani El Idrissi ${ }^{4}$ and Mohamed Rhajaoui ${ }^{1}$

\begin{abstract}
Background: This is the first study in Morocco to estimate snail infection rates at the last historic transmission sites of schistosomiasis, known to be free from new infection among humans since 2004. Screening of large numbers of snails for infection is one way to confirm that Schistosoma haematobium transmission has stopped and does not resurge.

Methods: A total of 2703 Bulinus truncatus snails were collected from 24 snail habitats in five provinces of Morocco: Errachidia, El Kelaa des Sraghna, Tata, Beni Mellal, and Chtouka Ait Baha. All visible snails were collected with a scoop net or by hand. We used waders and gloves as simple precautions. Snails were morphologically identified according to Moroccan Health Ministry guide of schistosomiasis (1982).

All snails were analyzed in pools by molecular tool, using primers from the newly identified repeated DNA sequence, termed Dral, in the S. haematobium group. To distinguish S. bovis and S. haematobium, the snails were analyzed by Sh110/Sm-SI PCR that was specific of S. haematobium.

Results: The results showed that snails from Errachidia, Chtouka Ait Baha, sector of Agoujgal in Tata and sector of Mbarkiya in El kelaa des Sraghna were negative for Dral PCR; but, snails from remaining snail habitats of El Kelaa des Sraghna, Tata and Beni Mellal were positive. This led to suggest the presence of circulating schistosome species (S. haematobium, S. bovis or others) within these positive snail habitats. Subsequently, confirmation with S. haematobium species specific molecular assay, Sh110/Sm-SI PCR, showed that none of the collected snails were infected by $S$. haematobium in all historic endemic areas.
\end{abstract}

Conclusion: The absence of $\mathrm{S}$. haematobium infection in snails supports the argument of $\mathrm{S}$. haematobium transmission interruption in Morocco.

Keywords: Schistosomiasis, Elimination, Bulinus truncatus, Schistosoma haematobium, Dral PCR, Sh110/Sm-SI PCR, Morocco

\section{Background}

In Morocco, urinary schistosomiasis caused by Schistosoma haematobium, was first diagnosed in 1914 in Marrakech, and was severely endemic until 1981. Schistosomiasis control has been given a high priority in public health work since 1982 [1]. A four pronged control strategy was

\footnotetext{
* Correspondence: Fatima_inh@yahoo.fr

'Laboratory of Parasitology, Department of Parasitology, National Institute of Hygiene, Agdal, Rabat, Morocco

${ }^{3}$ Department of Biology, University of Mohammed V, Agdal, Rabat, Morocco Full list of author information is available at the end of the article
}

employed consisting of (i) annual screening and treatment of human cases, including increased intensity of case detection in health centers and by mobile teams; (ii) malacological control by means of mollusciciding and environmental management (depending on the ecological setting) as a collaborative effort between health, agriculture, forestry, and water resource sectors; (iii) health education and community mobilisation; and (iv) intersectoral collaboration with involvement of services from administration, health, agriculture and education, at local and provincial levels [2]. 
Great achievements have been seen during the last three decades. The number of schistosomiasis patients dropped from 35596 cases in 1983 to 95 cases in 2003 [3,4]. The regular control efforts and the rainfall deficit (>20\%) during 1990-2000 that resulted in the natural drying of irrigation canals decreased densities and snail habitats of Bulinus truncatus, a snail which acts as the intermediate host of S. haematobium, from 14 provinces with positive B. truncatus habitats in 1983 to 7 provinces in 2006 [3-5]. By 2004, the likely interruption of S. haematobium transmission had been achieved at national level. Five years after, the process of confirming the interruption of transmission and possible certification of elimination was started with a national serological survey of human schistosomiasis haematobium among children born during the elimination phase of the control program. The results showed absence of positive cases [6].

To complement the human testing, study of cercarial shedding by snails is the most useful approach to estimate human to snail transmission. However, cercarial shedding can be highly focal and of low frequency, even in areas of significant transmission [7]. Indeed, considering that prepatent infection can last for several weeks with only a proportion of snails reaching the stage of cercarial shedding, that mortality of infected snails can be higher after cercarial shedding, and that in cold seasons sporocyst development is delayed, it can be assumed that prepatent infection rates can be substantial, and will variably exceed patent infection rates over time [8]. Detection of schistosomal antigens in snail hemolymph is a better predictor of prevalence than cercarial shedding; it is suitable for large-scale screening and detection and more sensitive. However, detection of antigens actively secreted by developing parasites obviously cannot be used as a suitable marker for early infection, but more as an indicator of prepatent and patent infections [9].

In the other hand, those assays cannot discriminate $S$. haematobium from other parasites, especially $S$. bovis that may co-exist in naturally infected snails and may pose problems for the differential diagnosis based on morphology. Molecular tool, such as DraI PCR, had been used in coastal Kenya. The assay was practical for large scale monitoring of S. haematobium transmission in affected communities, cheaper and the detection limit was less than $10 \mathrm{fg}$ of Schistosoma DNA [10,8,11]. The DraI sequence, not found in S. mansoni and S. japonicum, and present in DNA of other schistosomes belonging to the S. haematobium group [8], represent $15 \%$ of the S. haematobium genome. Because of the abundance of the sequences, the PCR of DraI sequence could detect very low amount of DNA.

To differentiate the member within the group, PCR of Sh110/Sm-Sl is important. DNA from $S$. bovis was not amplified at all, while S. intercalatum and S. curassoni could be differentiated from S. haematobium by the different banding pattern of their amplification products. The
Sh110/Sm-Sl PCR products constitute $0.002 \%$ of the genome. This PCR can detect $1 \mathrm{pg}$ of S. haematobium, and it is very sensitive and specific [10]. Furthermore, the PCR assay is characterized by lower dependence on participation by local population, amenable to automation and high-throughput testing $[11,12]$.

\section{Methods}

\section{Study area}

We chose the provinces with histories of recent transmission of schistosomiasis, and presence of snail intermediate hosts habitats: Chtouka Ait Baha, Errachidia, El Kelaa des Sraghna, Tata, and Beni Mellal (Figure 1). In each province, we selected sectors and localities where the last known cases were detected. Chtouka Ait Baha has a semi arid climate. The sector of Targa NTouchka was chosen because it represented a hot spot of urinary schistosomiasis and where the last cases were detected in 2003 [13]. Errachidia has a Saharan climate. Locality of Meski, selected in this study, is situated on Oued Ziz, origin of eighty percent of cases in the past. The last case was reported in 2004 [14]. Tata has a Saharan climate. The first serological study, conducted in 2001, showed that sector of Rahala was the hot spot of schistosomiasis [15]. Then we selected this sector and two other sectors in the proximity. El Kelaa des Sraghna province has a semi arid and arid climate. It is a site with history of high incidence and where the last case was detected in 2000 [16]. Beni Mellal has a continental climate. Urinary schistosomiasis was highly endemic in the irrigated agriculture areas (sector of Kourifat and sector of Bouaker). The last two cases were detected in 2000 [16].

\section{Snail collection}

In April 2008, investigations were carried out in any suspected positive site within the chosen sectors. Snails were collected each morning for one week in each snail habitat and they were identified in situ by experienced staff. Each 5 to 10 snails, were directly placed in ethanol (70\%), and then sent to the laboratory of Parasitology, National Institute of Hygiene at Rabat for morphological examination, identification to species level, and molecular tests for Schistosoma parasite identification.

To accurately pinpoint all snails presents in each snail habitat, despite of the continuous chemical and physical treatment, all technicians have chosen the hot season (between April and July) in their respective province, when a probable rapid increase in snail density associated with an increase in temperature was generally observed [17].

\section{PCR detection of S. haematobium in snails}

Extraction of DNA: The hexadeclytrimethylammonium bromide (CTAB) method was used as previously described $[10,18]$. Briefly, three to five snails based on their 


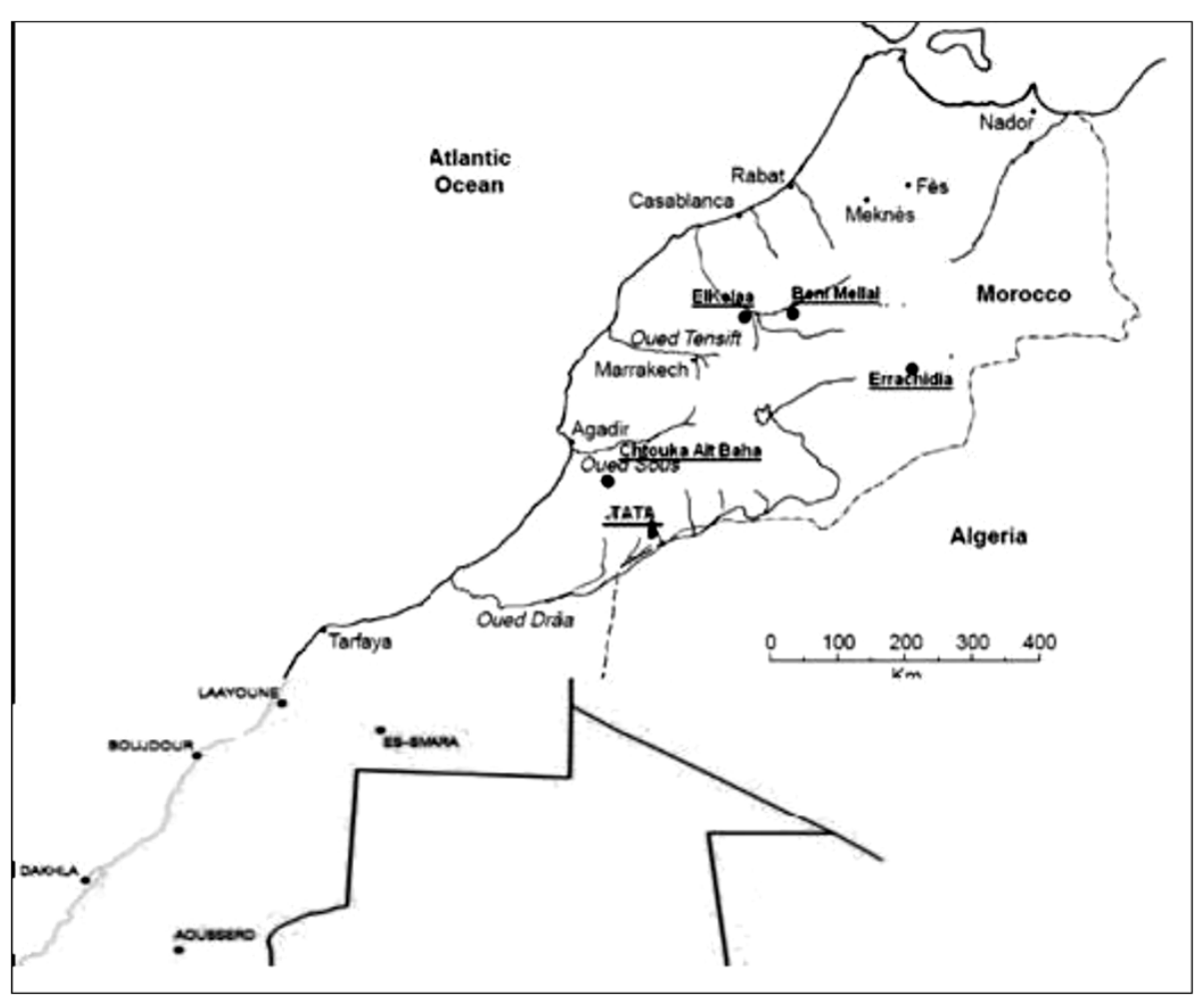

Figure 1 Moroccan map showing selected areas in the study and principal rivers.

sizes (estimated to $50 \mathrm{mg}$, and equal, constant number of snails per group may be better), were crushed and the soft tissue of snails was incubated in lysis buffer $(100 \mathrm{mM}$ Tris $-\mathrm{HCl} \mathrm{pH}$ 7.5, $20 \mathrm{mM}$ EDTA, 1.4 M NaCl, 2\% CTAB, and $0.2 \% 2$-Mercaptoethanol) with $500 \mu$ l proteinase $\mathrm{K}$ $(10 \mathrm{mg} / \mathrm{ml})$, at $60^{\circ} \mathrm{C}$ for 1 to 2 hours until complete digestion. If we use constant number of snails, proteinase $\mathrm{K}$ must be added according to the total mass of snail. This was followed by phenol/chloroform DNA extraction and by ethanol precipitation using $3 \mathrm{M}$ sodium acetate and cold ethanol. The precipitated DNA was washed with ethanol 70\%, dried, and dissolved in $50 \mu \mathrm{l}$ of TE buffer.

Amplification by DraI PCR: DraI PCR was carried out in a volume containing $200 \mu \mathrm{M}$ dNTPs, $25 \mathrm{pMol}$ of each DraI primers (forward: GATCTCACCTATCAGACG, reverse: GTCACCAATAATATGAAAC), 2.5 units of Taq DNA polymerase, and $5 \mu \mathrm{l}$ of target DNA (not diluted). The final volume for PCR reaction was $50 \mu \mathrm{l}$. All PCR assays were carried out by initial denaturation at $95^{\circ} \mathrm{C}$ for $5 \mathrm{~min}, 35$ cycles of $95^{\circ} \mathrm{C}$ for $1 \mathrm{~min}, 72^{\circ} \mathrm{C}$ for $1 \mathrm{~min}$, followed by final elongation at $72^{\circ} \mathrm{C}$ for $10 \mathrm{~min}$, and then held at $4^{\circ} \mathrm{C}$. If the result of DraI PCR that detects Schistosoma DNA was positive, we amplified Sh110$\mathrm{SmSl}$ that was specific for S. haematobium.

Amplification by Sh110/Sm-Sl PCR: We used a primer that is targeting a novel repeat sequence of $S$. haematobium: the 525 base pair Sh110 repeat (Sh110: 5'- TTC
CTC CAA CTA CCA TCT TAT CTC-3'), and a second primer that was derived from the $S$. mansoni splice leader sequence Sm-SL (Sm-Sl: 5'- AAC CGT CAC GGT TTT ACT CTT GTG-3'). These primers were employed in PCR assays for species-specific discrimination between S. haematobium DNA and DNA of other related animal schistosome species. The method used for amplification was identical to that of DraI PCR.

For detecting S. haematobium-infected snails by PCR, preliminary experiments were carried out for establishing the optimal conditions for DNA extraction and PCR. Electrophoresis: The amplified DNA products were resolved by agarose gel electrophoresis and stained with ethidium bromide for visual detection by UV transillumination. If the band revealed on gel, was bright, indicating high concentration of PCR product, we diluted DNA of $1 / 10$ in PBS.

Positive and negative controls: In each PCR assay, $10 \mathrm{ng}$ of S. haematobium purified DNA was used as a positive control and negative control was the water.

\section{Results}

Abundance of snails

Snail habitats of Errachidia, El Kelaa des Sraghna, Tata, Beni Mellal and Chtouka Ait Baha varied significantly over time by observation of the number of $B$. truncatus snails. Chtouka Ait Baha represented a hot spot of B. truncatus 
with 960 snails. In contrast, snail habitats of Errachidia were the poorest one (101 snails). A total of 2703 snails were collected from all snail habitats, and they are divided into 651 groups of snails.

\section{Results of Dral PCR}

The molecular identification of snails for infection by $S$. haematobium gave varying results among the province and snails habitat within the same province. Molecular identification of Schistosoma spp by DraI PCR showed that none of the snails collected in Errachidia and Chtouka Ait Baha provinces were infected. Also, in Agoujgal locality and one snail habitat (named Mbarkia) in sector of Ouled Marrek, respectively in Tata and El kelaa des Sraghna provinces, none of the snails were infected (Table 1 and Figure 2).

\section{Results of Sh110 SmSI PCR}

Snails collected from Beni Mellal province and remaining localities of El Kelaa and Tata province were positive by DraI PCR. That suggested the presence of circulating schistosome species (S. haematobium, $S$ bovis or others). Confirmation by Sh110/Sm-Sl PCR showed none of DraI PCR positive collected snails were infected by $S$. haematobium (Figure 3).

\section{Discussion}

When prevalence has dropped to a very low level, or is presumed to be zero, looking for infection in snails is probably the best way to monitor transmission, confirm its absence, and monitoring re-emergence of schistosomiasis. Molecular mass screening of pools of snails for schistosomal infection enables coverage of large areas. It is particularly important for periodical monitoring where the prevalence of snail infection is very low and only a few infected snails can be found among thousands of uninfected ones (particularly during the maintenance phase after effective control, or in new water development schemes where the danger of the spread of schistosomiasis exists). The use of this approach in developing countries, requires further studies to be applied to a variety of conditions and to prove the cost effectiveness of the method [19].

In our study, one test PCR test costs about 7 USD; by pooling the DNA into 651 groups of 2703 snails has reduced to $76 \%$ the total cost than if we analyze snail by snail.

DraI PCR allows detection of infected snails one hour after snail exposure to miracidia. Thus, it identifies the entire population of infected snails, regardless of whether they eventually shed cercariae, representing in quantitative terms the direct outcome of human contamination of water bodies [8]. This approach has been applied to largescale monitoring of infection in field snails at transmission sites in Coast Province, Kenya [10]. The sensitivity of this assay was demonstrated by detection of $10 \mathrm{fg}$ of $S$. haematobium DNA $[8,10,11]$. DraI was not found in S. mansoni or $S$. japonicum by dot hybridization. However, because the DraI repeat is present in DNA of other schistosomes belonging to the $S$. haematobium group [18], the identification of S. haematobium-infected snails by a simple PCR assay has been limited, thus far, to areas where these other S. haematobium-related schistosome species are absent or very rare [8]. Negative results by DraI PCR of snails collected from Errachidia and Chtouka Ait Baha confirm the absence of $S$. haematobium human to snail transmission. However, positive results by DraI PCR, of snails collected from Tata, El Kelaa des Sraghna, and Beni Mellal, suggest S. haematobium infection of snails or cross-amplification assays with DNA from a variety of animal schistosomes [19]. S. bovis is the most widespread and prevalent species $[20,21]$, and thus has the widest potential geographical overlap with $S$. haematobium. The other animal schistosomes' species are less widely distributed. $S$. mattheei is found in southern Africa [20], S. margrebowiei is found in a relatively small area in west and southern Central Africa [20], S. curassoni is found primarily in western Africa $[20,22]$, and $S$. intercalatum, belong to the same group and causing sporadic schistosomiasis in humans, is found in foci in central Africa within Equatorial Guinea, Sao Tome, Nigeria, and Mali [23].

Consequently, DraI PCR cannot discriminate human and animal foci of schistosomiasis in those three areas and thus required to analyse the positive snails by the second Sh110/ Sm-Sl PCR. The negative result of Sh110/Sm-Sl PCR but, DraI PCR positive result could be due to the cross reaction to S. bovis; El Kelaa des Sraghna, Tata and Beni Mellal contain the national's largest ovine and bovine populations.

These approaches will allow extension of large-scale PCR monitoring for snails infected with S. haematobium [10], which had been previously limited to areas where cross-reacting (DraI containing) animal schistosome species were absent or very rare. However, the use of two PCR may take more time and products. A drawback of using Sh110 SmSl PCR alone or DraI PCR alone, in a coendemic area is that they would not be able to detect mixed populations of $S$. haematobium and S. bovis. Recently, Webster et al., present a high-throughput one-step multiplex COX1 PCR diagnostic method to detect and discriminate between S. haematobium and S. bovis, and enables the discrimination between false negatives and failed Sh110SmSl PCRs (used alone). The detection sensitivity of COX1 PCR is $0.8 \mathrm{ng}$ of genomic DNA [24]. However, the estimated DNA concentration of a single miracidium is about $1-2 \mathrm{ng} / \mathrm{ml}$, and taking into consideration that less than a tenth of the extracted DNA is used for amplification, and that assay was not tested for direct identification of infected snails, the COX1-based assay, was further 
Table 1 Dral and Sh110/Sm-SI PCR results of different collected snails in different sectors and localities

\begin{tabular}{|c|c|c|c|c|c|}
\hline Province & Locality & Snails habitats & $\begin{array}{l}\text { Number of snails collected } \\
\text { (number of screening } \\
\text { group of } 3 \text { to } 5 \text { snails) }\end{array}$ & $\begin{array}{l}\text { Number of positive } \\
\text { snail goups For Dral } \\
\text { (and \%) }\end{array}$ & $\begin{array}{l}\text { Number of positive } \\
\text { snail goups for } \\
\text { Sh110/SmSI (and \%) }\end{array}$ \\
\hline \multirow[t]{5}{*}{ Chtouka Ait Baha } & \multirow[t]{5}{*}{ Targa NTouchka } & Aghou Niguer & $200(52)$ & 0 & - \\
\hline & & Takchirane/Tizghine & $200(48)$ & 0 & - \\
\hline & & Timintoudroute & $250(66)$ & 0 & - \\
\hline & & Doussaghouch & $210(54)$ & 0 & - \\
\hline & & Tamda N'Benmouss & $100(24)$ & 0 & - \\
\hline Chtouka Ait Baha total & & 5 & $960(224)$ & 0 & - \\
\hline \multirow[t]{3}{*}{ Errachidia } & \multirow[t]{3}{*}{ Meski Oued Ziz } & Agmmatine and Rjel & $12(4)$ & 0 & - \\
\hline & & Louidi & $30(7)$ & 0 & - \\
\hline & & Seguia Meski & $59(13)$ & 0 & - \\
\hline Errachidia total & & 3 & $101(24)$ & 0 & - \\
\hline \multirow[t]{7}{*}{ Tata } & \multirow[t]{2}{*}{ Agoujgal (2) } & Agoujgal/tagoujgalt & $150(34)$ & 0 & - \\
\hline & & Agoujgal/toufssirt & $150(36)$ & 0 & - \\
\hline & \multirow[t]{3}{*}{ Rahala (3) } & Rahal/ain tahafit & $40(12)$ & $6(3)$ & 0 \\
\hline & & Rahal/ain imazighen & $60(18)$ & $10(5)$ & 0 \\
\hline & & Rahala/ain issoukine & $50(14)$ & $5(2.5)$ & 0 \\
\hline & \multirow[t]{2}{*}{ Taourirt (2) } & Taourirt/ain tichoute & $100(32)$ & $22(11)$ & 0 \\
\hline & & Taourirt/ain tihirite & $50(12)$ & $12(6)$ & 0 \\
\hline Tata total & & 7 & $600(158)$ & 55 (27.6) & 0 \\
\hline \multirow[t]{6}{*}{ El Kelaa des Sraghna } & \multirow[t]{2}{*}{ Ouled Marrek } & Mbarkia & $107(34)$ & $0(0)$ & - \\
\hline & & Noujania & $3(1)$ & $1(0.5)$ & 0 \\
\hline & Coop Falah & D7 & $77(17)$ & $9(4.5)$ & 0 \\
\hline & Coop Chabab & D6 & $142(38)$ & $20(10)$ & 0 \\
\hline & \multirow[t]{2}{*}{ Coop Hahadia } & D3 & $83(41)$ & $2(1)$ & 0 \\
\hline & & OGG2 & $20(4)$ & $2(1)$ & 0 \\
\hline El Kelaa des Sraghna total & & 6 & $432(99)$ & $34(17.08)$ & 0 \\
\hline \multirow[t]{3}{*}{ Beni Mellal } & \multirow[t]{2}{*}{ Laasara } & SD7 10 & $160(32)$ & $25(12.57)$ & 0 \\
\hline & & SD6 & $150(30)$ & $24(12.06)$ & 0 \\
\hline & Oulad Abdoun-krifate & D4 & $300(84)$ & $61(30.65)$ & 0 \\
\hline Beni Mellal total & & 3 & $610(146)$ & $110(55.3)$ & 0 \\
\hline Grand total & & 24 & $2703(651)$ & 199 (100) & 0 \\
\hline
\end{tabular}

"-": We dont analyze Dral PCR negative snails.

refined for use in real-time PCR, with higher detection sensitivity (pg range) [25,26]. More recently, Abassi et al. develop a simple and more sensitive PCR assay that enables direct discrimination of $S$. haematobium from related animal schistosomes, by the primer combination of DraI reverse primer and Sh73 direct primer (73d). The sensitivity of $S$. haematobium detection was $1 \mathrm{pg}$, whereas S. bovis detection was $10 \mathrm{pg}$. It can be assumed that detection of snails infected with $S$. haematobium will be accomplished from very early prepatency. Such assays required further validation using larger numbers of field snails for large scale monitoring of post-intervention residual transmission [25].
Our approache using two simultaneous PCR, DraI PCR and Sh110 SmSl PCR, allowed a good sensitive detection of snails infected with $S$. haematobium from very early prepatency $(1 \mathrm{pg})$ in the maintenance elimination phase of urinary schistosmiasis in Morocco [27]. Also, PCR has been shown to be practical for large-scale monitoring of $S$. haematobium transmission in affected communities [10], collection of snails is simple and can be done by village workers [28], the simple CTAB DNA extraction procedure greatly eliminate the inhibitors, and establishment of the PCR approach for monitoring infected snails with low cost should be developed. Extraction of collected snails in EDTA was shown as suitable for long-term preservation 


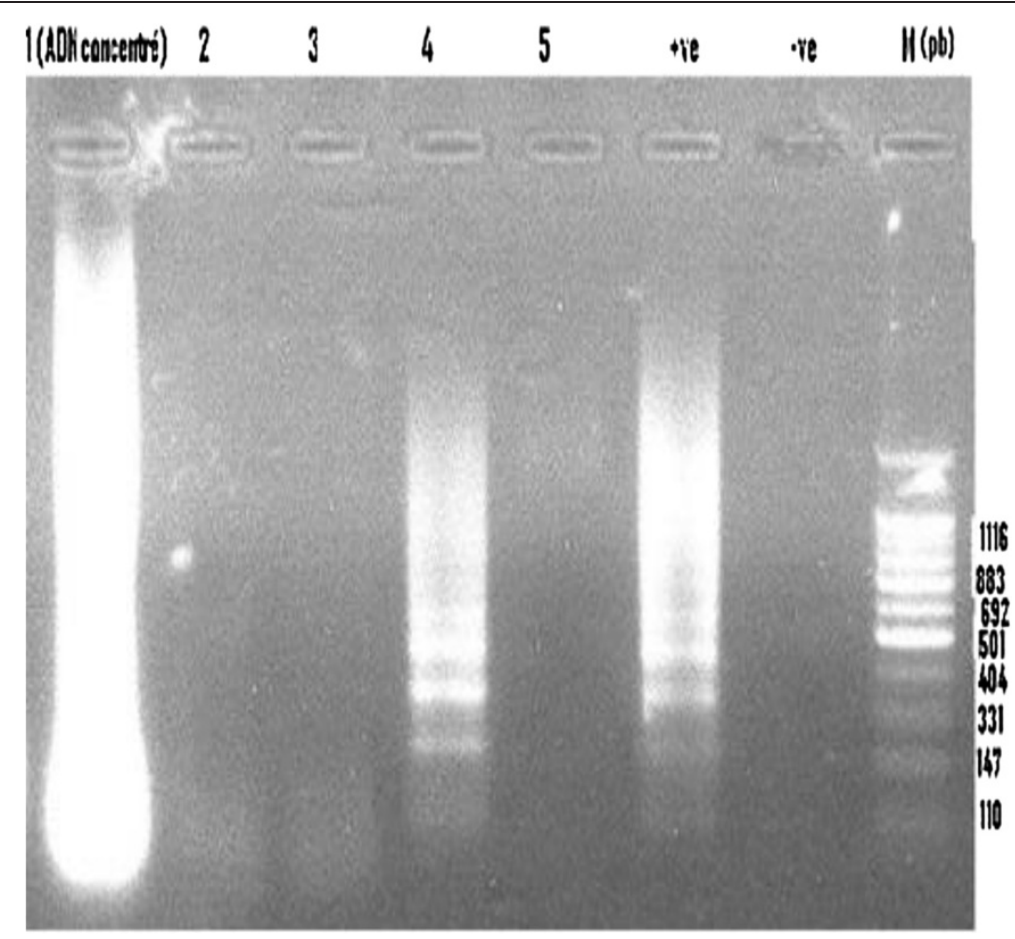

Figure 2 Agarose gel electrophoresis analysis of Dral PCR amplified products from different collected snails. Lane 1-5: (pool of 5 snails was tested per lane; Lane 1 and 4: Positive snails; Lane 2,3,5: Negative snails, Lane + ve: Positive control; Lane ve-: Negative control, and M: size marker (base pair).

of the DNA at ambient temperature (Hamburger J and others, unpublished data), as has been previously shown with blood and sputum [19]. Although DraI PCR and Sh110 SmSl were highly sensitive and specific for $S$. haematobium detection, research of novel primers that can differentiate human and animal schistosomes simultaneously will greatly decrease the cost of the assays [7]. The use of Loop-Mediated Isothermal Amplification (LAMP) will decrease the cost further down and more field friendly. Studies of feasibility of using LAMP for field studies should be developed [27].

The fact that all snails from the five historic endemic provinces were negative for $S$. haematobium infection, absence of autochthonous parasite since 2004, absence of circulating parasite among children age school demonstrated by the serological study in 2009 [6], support the absence of haematobium focus (human and snails) whatever the epidemiological statut of S. bovis (animal

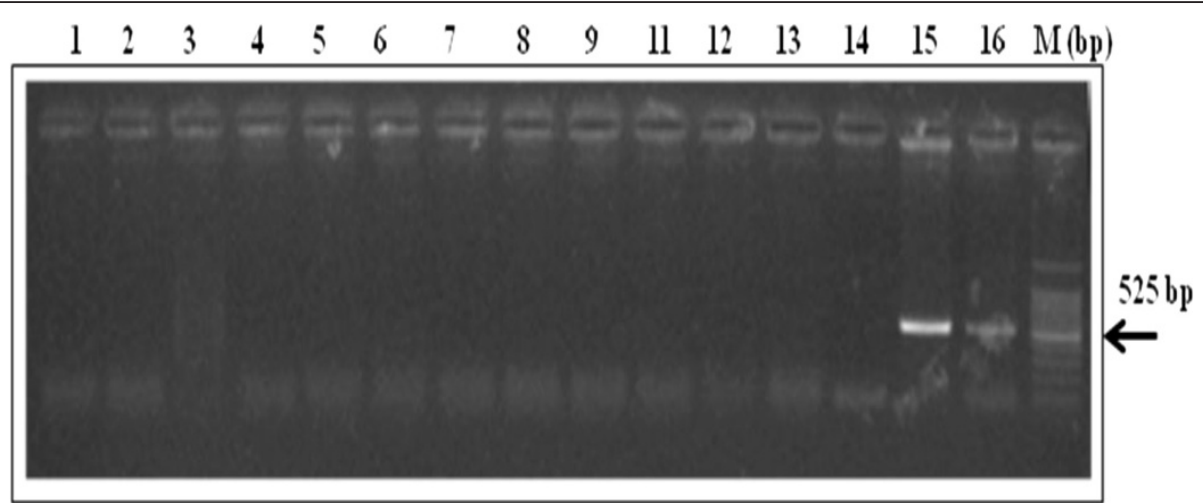

Figure 3 Agarose gel electrophoresis analysis of Sh110/Sm-SI PCR amplified products from different collected snails. Lane 1-11: pool of 5 snails was tested per lane; Lane 12: Negative control; Lane 13 and 14: DNA preparation negative control; Lane 15: Spiking control (S. haematobium DNA was added to known negative snail tissue), Lane 16: Positive control (pure S. haematobium DNA), and. M: size marker (base pair). 
specie), and that may ensure that transmission does not re-establish

Planorbarius metidjensis, experimental intermediate host of S. haematobium in south of Morocco, living at high altitude, from $340 \mathrm{~m}$ to $1380 \mathrm{~m}$ [29], was not collected. However, the fact that, the parasite was not autochthonous in all historic endemic areas since 7 years, and the natural intermediate host of $S$. haematobium in Morocco, B. truncatus, was uninfected, led to the assumption that the life cycle of S. haematobium is interrupted whatever the intermediate host is.

Here, we caution that some factors - human movement between Morocco and endemic countries, low sensitivity/ specificity of current diagnostic tools, changes in environmental and socio-economic factors- may pose obstacles towards the mantain of elimination, and prevention of reemergence of the parasite [30]. Health education should be given to those who will go to the endemic areas to improve their knowledge and awareness on prevention and control of haematobium schistosomiasis, there by reducing the risk of exposure to the infested freshwater [31]. Serological survey, and the developpement of highly variable DNA markers, to investigate the genetic epidemiology of $S$. haematobium within both definitive mammalian and intermediate snail hosts is greatly suitable in elimination phase of schistosomiasis in Morocco [32].

\section{Conclusion}

We have shown that molecular tools using pooled snail extracts to testing large sample of snails is feasible and allow to monitor reemergence of schistosomiasis in Morocco. Combination of serological [6] and present malacological surveys reinforce the arguments of interruption of schistosomiasis transmission in Morocco. However, serious challenges for the control program exist due to the limitation of control of immigration from endemic countries and limitation of scientific technology [33].

\section{Competing interests}

The authors declare that they have no competing interests.

\section{Authors' contributions}

The study was designed by RM and LA. The database of collected snails was communicated by NH, HF and AB. The PCR analysis of snails and interpretation of the results was carried out by A.F and SF. Our PCR results interpretation was revised by Al. AF prepared the draft article. RM, SF, SH, and A.I provided source documents and contributed comments on the draft article. All authors gave final approval of the version for publication. RM coordinated the project with $\mathrm{WHO}$ and is the guarantor of the article.

\section{Acknowledgments}

The authors thank the personal of the five provinces for their cooperation and to the team from the Parasitology department of INH for supporting the work. We also thank Prof Sukwan Handali from Division of Parasitic Diseases, Centers for Disease Control and Prevention, Atlanta, Georgia, and Dr Chistulo Lester, World Health Organisation's expert, for comments and carefully revising the English grammar of this paper. This paper is dedicated to the team and the memory of two personnel of schistosomiasis and malacological reference laboratory of $\mathrm{NIH}$ at Rabat who made great contributions to the interruption of schistosomiasis transmission since 1980.

\section{Financial support}

This study was supported by the World Health Organization (Reference no. 2 008/237-0).

\section{Author details}

${ }^{1}$ Laboratory of Parasitology, Department of Parasitology, National Institute of Hygiene, Agdal, Rabat, Morocco. ${ }^{2}$ Department of Biology, Faculty of Science and Technology, Al Quds University, Jerusalem, Palestine. ${ }^{3}$ Department of Biology, University of Mohammed V, Agdal, Rabat, Morocco. ${ }^{4}$ Direction of Epidemiology and Control of Diseases, Ministry of Health, Rabat, Morocco.

Received: 21 October 2013 Accepted: 3 June 2014

Published: 24 June 2014

\section{References}

1. Barkia H, Barkia A, Nhammi H, Belghyti D: La schistosomiase au Maroc: de sa découverte à l'après-élimination. East Mediterr Health J 2011, 17:3.

2. Rollinson D, Knopp S, Levitz S, Stothard JR, Tchuem Tchuenté LA, Garba A, Mohammed KA, Schur N, Person B, Colleyk DG, Utzinger J: Time to set the agenda for schistosomiasis elimination. Acta Trop 2013, 128(2):423-440.

3. Ministry of Health, Direction of Epidemiology and control of Diseases, Morocco: Rapport d'activité annuel des programmes de lutte contre les maladies parasitaires. Bull épidémiologique 1983, 1:11-14.

4. Ministry of Health, Direction of Epidemiology and control of Diseases, Morocco: Rapport d'activité annuel des programmes de lutte contre les maladies parasitaires. Bull épidémiologique 2013, 1:28.

5. Ministry of Health, Direction of Epidemiology and control of Diseases, Morocco: Etat d'avancement des programmes de lutte contre les maladies parasitaires. Bull épidémiologique 2006, 1:45.

6. Amarir F, El Mansouri B, Fellah H, Sebti F, Lakranbi M, Laamrani El Idrissi A, Sadak A, Rhajaoui M: National Serological Survey of Haematobium Schistosomiasis in Morocco: arguments to explain the elimination. Am J Trop Med Hyg 2011, 1:15-19.

7. Abbasi I, King CH, Muchiri EM, Hamburger J: Detection of Schistosoma mansoni and Schistosoma haematobium DNA by loop-mediated isothermal amplification: identification of infected snails from early prepatency. Am J Trop Med Hyg 2010, 83:427-432.

8. Hamburger J, Hoffman O, Kariuki HC, Muchiri EM, Ouma JH, Koech DK Sturrock RF, King CH: Large-scale, polymerase chain reaction-based surveillance of Schistosoma haematobium DNA in snails from transmission sites in coastal Kenya: a new tool for studying the dynamics of snail infection. Am J Trop Med Hyg 2004, 71:765-773.

9. Hambourger J: Schistosoma mansoni antigene recognized in Biomphalaria glabrata hemolymphe by monoclonal antibodies. Am J Tropical Med Hygiene 1989, 40:605-612.

10. Abassi I, Charles K, Robert FS, Curtis K, Eric M, Joseph H: Differentiation of Schistosoma haematobium from related schistosomes by PCR amplifying an inter repeat sequence. Am J Trop Med Hyg 2007, 76:950-955.

11. Melo FL, Gomes AV, Barbosa CS, Werkhauser RP, Abath FGC: Development of molecular approaches for the identification of transmission sites of schistosomiasis. Trans R Soc Trop Med Hyg 2006, 100:1049-1055.

12. King $\mathrm{CH}$, Sturrock RF, Kariuki HC, Hamburger J: Transmission control for schistosomiasis - why it matters now. Trends Parasitol 2006, 22:12.

13. Ministry of Health, Direction of Epidemiology and control of Diseases, Morocco: Rapport d'activité annuel des programmes de lutte contre les maladies parasitaires. Bull épidémiologique 2003, 1:25.

14. Ministry of Health, Direction of Epidemiology and control of Diseases, Morocco: Rapport d'activité annuel des programmes de lutte contre les maladies parasitaires. Bull épidémiologique 2004, 1:31.

15. Ministry of Health, Direction of Epidemiology and control of Diseases, Morocco: Rapport d'activité annuel des programmes de lutte contre les maladies parasitaires. Bull épidémiologique 2001, 1:31.

16. Ministry of Health, Direction of Epidemiology and control of Diseases, Morocco: Rapport d'activité annuel des programmes de lutte contre les maladies parasitaires. Bull épidémiologique 2000, 1:41-42.

17. Moussa AH, Abou El-Hassan AA: The effect of water temperature on the snail intermediate hosts of schistosomiasis in Egypt. Egyptian Med SoC 1972, 55:148-165. 
18. Hambourger J, Na H, Abbasi I, Ramzy RM, Jourdane J, Ruppel A: Polymerase chaine reaction assay based on a highly repeated sequence of Schistosoma haematobium: a potential tool for monitoring schistosomeinfested water. Am J Trop Med Hyg 2001, 65:907-911.

19. Hambourger J, Na H, Xin XY, Ramzy RM, Jourdane J, Ruppel A: A polymerase chain reaction assay for detecting snails infected with bilharzia parasites (Schistosoma mansoni) from very early prepatency. Am J Tropical Med Hygiene 1998, 59:872-876.

20. Christensen NO, Mutani A, Frandsen F: A review of the biology and transmission ecology of African bovine species of the genus Schistosoma. Z Parasitenkd 1983, 69:551-570.

21. Mone H, Mowahid G, Monard S: The distribution of Schistosoma bovis Sonsino, 1876 in relation to intermediate host mollusc-parasite relationship. Adv Parasitol 2000, 44:100-138.

22. Vercruysse J, Southgate VR, Rollinson D, DeClerca D, Sacko M, De Bont J, Mungomba LM: Studies on transmission and schistosome interactions in Senegal, Mali, and Zambia. Trop Geogr Med 1994, 46:220-226.

23. Jourdane J, Southgate VR, Pages JR, Durand P, Tchuente LAT: Recent studies on Schistosoma intercalatum: taxonomic status, puzzling distribution, and transmission foci revisited. Mem Inst Oswaldo Cruz 2001, 96:45-48.

24. Webster BL, Rollinson D, Stothard JR, Huyse T: Rapid diagnostic multiplex PCR (RD-PCR) to discriminate Schistosoma haematobium and S. bovis. J Helminthol 2010, 84:107-114.

25. Abbasi I, Hamburger J, Kariuki C, Mungai PL, Muchiri EM, King CH: Differentiating Schistosoma haematobium from Related Animal Schistosomes by PCR. Amplifying Inter-Repeat Sequences Flanking Newly Selected Repeated Sequences. Am J Trop Med Hyg 2012, 87(6):1059-1064.

26. Huyse T, Webster BL, Geldof S, Stothard RJ, Diaw OT, Polman K, Rollinson D: Bidirectional introgressive hybridization between a cattle and human schistosome species. PLoS Pathog 2009, 5(9):e1000571.

27. WHO: Elimination of schistosomiasis from low-transmission areas. Report of Who informal consultation, Salvador, Brazil 2008, 1-21.

28. Sturrock RF: Snail collection to detect schistosome transmission sites. Parasitol Today 1986, 2:59-63.

29. Yacoubi B, Zekhnini A, Moukrim A, Rondelaud D: Bulins, planorbes et endémie bilharzienne dans le sud-ouest marocain. Bull Soc Pathol Exot 2007, 100:174-175.

30. Zhou YB, Liang S, Jiang QW: Factors impacting on progress towards elimination of transmission of schistosomiasis japonica in China. Parasites Vectors 2012, 5:275.

31. Hua HY, Wang W, Cao GQ, Tang F, Liang YS: Improving the management of imported schistosomiasis haematobia in China: lessons from a case with multiple misdiagnoses. Parasites Vectors 2013, 6:260.

32. Glenn CT, Lance SL, McKee AM, Webster BL, Emery AM, Zerlotini A Oliveira G, Rollinson D, Faircloth BC: Significant variance in genetic diversity among populations of Schistosoma haematobium detected using microsatellite DNA loci from a genome-wide database. Parasites Vectors 2013, 6:300.

33. Utzinger J, N'Goran EK, Caffreye CR, rKeiser J: From innovation to application: Social-ecological context, diagnostics, drugs and integrated control of schistosomiasis. Acta Trop 2011, 120:121-137.

doi:10.1186/1756-3305-7-288

Cite this article as: Amarir et al.: Schistosoma haematobium detection in snails by Dral PCR and Sh110/Sm-SI PCR: further evidence of the interruption of schistosomiasis transmission in Morocco. Parasites \& Vectors 2014 7:288.

\section{Submit your next manuscript to BioMed Central and take full advantage of:}

- Convenient online submission

- Thorough peer review

- No space constraints or color figure charges

- Immediate publication on acceptance

- Inclusion in PubMed, CAS, Scopus and Google Scholar

- Research which is freely available for redistribution 